\title{
A comparative study of biodegradation of vinyl acetate by environmental strains
}

\author{
Izabela Greń • Agnieszka Gąszczak • Urszula Guzik • \\ Grażyna Bartelmus • Sylwia Labużek
}

Received: 25 April 2010 /Accepted: 25 August 2010/Published online: 12 September 2010

(C) The Author(s) 2010. This article is published with open access at Springerlink.com

\begin{abstract}
Four Gram-negative strains, E3_2001, EC1_2004, EC3 3502 and EC2 3502, previously isolated from soil samples, were subjected to comparative studies in order to select the best vinyl acetate degrader for waste gas treatment. Comparison of biochemical and physiological tests as well as the results of fatty acids analyses were comparable with the results of 16S rRNA gene sequence analyses. The isolated strains were identified as Pseudomonas putida EC3_2001, Pseudomonas putida EC1_2004, Achromobacter xylosoxidans EC3_3502 and Agrobacterium sp. EC2_3502 strains. Two additional strains, Pseudomonas fluorescens PCM 2123 and Stenotrophomonas malthophilia KB2, were used as controls. All described strains were able to use vinyl acetate as the only source of carbon and energy under aerobic as well as oxygen deficiency conditions. Esterase, alcohol dehydrogenase and aldehyde dehydrogenase were involved in vinyl acetate decomposition under aerobic conditions. Shorter degradation times of vinyl acetate were associated with accumulation of acetic acid, acetaldehyde and ethanol as intermediates in the culture fluids of EC3 2001 and KB2 strains. Complete aerobic degradation of vinyl acetate combined with a low increase in biomass was observed for EC3 2001 and EC1 2004 strains. In conclusion, P. putida $\mathrm{EC1} 2004$ is proposed as the best vinyl acetate degrader for future waste gas treatment in trickle-bed bioreactors.
\end{abstract}

\footnotetext{
A. Gąszczak · G. Bartelmus

Institute of Chemical Engineering, Polish Academy of Sciences, Bałtycka 5,

44-100 Gliwice, Poland

I. Greń $(\triangle) \cdot$ U. Guzik $\cdot$ S. Łabużek

Department of Biochemistry, Faculty of Biology

and Environment Protection, University of Silesia,

Jagiellońska 28,

40-032 Katowice, Poland

e-mail: izabela.gren@us.edu.pl
}

Keywords Vinyl acetate - VOCs · Biodegradation · Pseudomonas $\cdot$ Esterase $\cdot$ Dehydrogenase

\section{Introduction}

Numerous methods are used in the removal of different volatile organic compounds (VOCs) from gaseous streams (Kennes and Veiga 2001). Nowadays, biofiltration is thought to be the most cost-effective, reliable and environmentally friendly technology (Malhautier et al. 2005). In general, biofiltration is based on the transfer of pollutants from the air to the water phase, and subsequent decomposition by microorganisms to nontoxic metabolic end products, carbon dioxide and water as well as to biomass. Unfortunately, the formation of an excessive amount of biomass can sometimes take place, resulting in clogging of the bioreactor (Iliuta and Larachi 2004, 2005; Mendoza et al. 2004). Furthermore, decomposition of contaminants does not always lead to harmless products. Degradation of vinyl acetate goes through hydrolysis of the ester bond yielding acetic acid and vinyl alcohol. The latter quickly undergoes tautomerism to acetaldehyde (Nieder et al. 1990). Acetaldehyde reacts directly with DNA, causing formation of DNA-protein crosslinks and chromosomal aberrations in eukaryotic cells. The toxicity of acetaldehyde as well as other compounds containing the aldehyde group can be so high that reduction or even inhibition of growth of bacterial cells from the genus Pseudomonas was observed (Jakoby and Narrod 1958). A very simple mechanism of acetaldehyde toxicity reduction using strain V2 was described by Nieder et al. (1990). This strain posses oxidoreductase [EC 1.1.1.-] which, in the presence of NADH, reduces acetaldehyde to its alcohol form; the alcohol is then oxidised in the presence of $\mathrm{NAD}^{+}$. In this way, periodic increases in the concentration of toxic acetaldehyde can be controlled temporarily via conversion to ethanol. 
Selection of the bacterial strain seems to be the crucial step in the preparation of well-operating trickle-bed reactors in waste gas treatment technologies. In a previous paper, Greń et al. (2009) described the isolation of 41 morphologically distinct isolates able to grow in the presence of vinyl acetate. Four of these were found to grow continuously while vinyl acetate at a concentration of $400 \mathrm{~g} \mathrm{~m}^{-3}$ was applied every $24 \mathrm{~h}$. The aim of the present research was to carry out a comparative study on those four bacterial strains in order to chose the best vinyl acetate degrader. In addition the laboratory strain Pseudomonas fluorescens PCM 2123, and the environmental strain Stenotrophomonas malthophilia KB2 (Guzik et al. 2009) were used as controls. The isolated strains were described and analysed, and the dynamics of vinyl acetate degradation under aerobic and anaerobic conditions were verified. Activities of enzymes crucial for vinyl acetate decomposition were measured in crude cell extracts after induction. It is worth noting that vinyl acetate is used commonly nowadays for production of polyvinyl acetate, polyvinyl alcohol and other polymers that are exploited finally in the manufacture of building materials, printing inks, plastics, lacquers and paints. Despite the fact that vinyl acetate is recognised to be a widespread environment pollution (US EPA 2007), only Nieder et al. (1990) and Hatanaka et al. (1989) have described bacterial strains involved in vinyl acetate decomposition.

\section{Materials and methods}

\section{Microorganisms}

Strains: EC3_2001, EC1_2004, EC3_3502 and EC2_3502 were isolated from soil samples collected from ground on the site of Synthos S.A. in Oświęcim (Poland) (formerly Chemical Company Dwory S.A.) in August 2006 using an enrichment culture technique as described previously (Greń et al. 2009). Pseudomonas fluorescens strain PCM 2123 was purchased from The Polish Collection of Microorganisms, Institute of Immunology and Experimental Therapy in Wrocław. Stenotrophomonas maltophilia KB2 came from the collection of Department of Biochemistry, University of Silesia in Katowice, and was originally isolated from the activated sludge of a sewage treatment plant in Bytom Miechowice in Poland using the classical enrichment technique with phenol as a selection factor (Guzik et al. 2009). Strains were kept on nutrient agar slopes at $4^{\circ} \mathrm{C}$ and transferred to the new medium monthly.

\section{Biochemical identification}

The isolated strains were characterised phenotypically and biochemically using standard techniques (colony shape, size and colour on nutrient agar plate, catalase and oxidase test, etc.), according to Bergey's Manual of Determinative Bacteriology (Holt et al. 1994). Additional biochemical and physiological characteristics were determined using the API 20NE and API 20E system (BioMerieux, Lyon, France). Catalase activity was determined by the presence of bubbles in a $3 \% \mathrm{H}_{2} \mathrm{O}_{2}$ solution within 5 min of incubation (Takeuchi et al. 1996).

Isolation of fatty acids was performed according to Sasser (1990). Analyses of fatty acid methyl esters (FAMEs) were performed using an HP 5890 gas chromatograph (Hewlett Packard, Rolling Meadows, IL) equipped with an HP $25 \mathrm{~m} \times$ $0.2 \mathrm{~mm}$ cross-linked methyl-silicone capillary column. The initial oven temperature was $170^{\circ} \mathrm{C}$, increased $5^{\circ} \mathrm{Cmin}^{-1}$ to $260^{\circ} \mathrm{C}$, increased further by $40^{\circ} \mathrm{Cmin}^{-1}$ to $320^{\circ} \mathrm{C}$ and held constant for 1.5 min (Glucksman et al. 2000). Helium was used as the carrier gas. FAMEs were identified with Sherlock software (TSBA library, version 3.9, Microbial ID, Newark, $\mathrm{NJ}$ ), based on the calibration of retention times of standards run prior to sample analysis.

\section{Molecular identification}

Bacterial DNAs were isolated from pure cultures using the DNA Mini Prep Kit (Qiagen). For 16S rRNA gene amplification the bacteria-specific primers $8 \mathrm{~F}$ 5'AGTTTGAT CATCGCTCAG 3' and 1492R 5'GGTTACCTTGTTAC GACTT3' were used (Lonergan et al. 1996). Amplifications were carried out through a program consisting of initial denaturation at $94^{\circ} \mathrm{C}$ for $300 \mathrm{~s}, 3$ cycles at $94^{\circ} \mathrm{C}$ for $45 \mathrm{~s}$, $57^{\circ} \mathrm{C}$ for $30 \mathrm{~s}, 72^{\circ} \mathrm{C}$ for $120 \mathrm{~s} ; 3$ cycles at $94^{\circ} \mathrm{C}$ for $45 \mathrm{~s}$, $56^{\circ} \mathrm{C}$ for $30 \mathrm{~s}, 72^{\circ} \mathrm{C}$ for $120 \mathrm{~s} ; 3$ cycles at $94^{\circ} \mathrm{C}$ for $45 \mathrm{~s}, 55^{\circ} \mathrm{C}$ for $30 \mathrm{~s}, 72^{\circ} \mathrm{C}$ for $120 \mathrm{~s} ; 26$ cycles at $94^{\circ} \mathrm{C}$ for $45 \mathrm{~s}, 53^{\circ} \mathrm{C}$ for $30 \mathrm{~s}, 72^{\circ} \mathrm{C}$ for $120 \mathrm{~s}$; and a final elongation cycle at $72^{\circ} \mathrm{C}$ for $300 \mathrm{~s}$. Nucleotide sequencing of the genes was performed using a Big Dye ${ }^{\mathrm{R}}$ Terminator Cycle Sequencing Kit (Applied Biosystems, Foster City, CA) and AbiPrism ${ }^{\circledR} 3100$ Genetic Analyzer. The MegaBLAST program was used for homology searches with the standard program defaults. Multiple sequence alignments were performed and the neighbourjoining phylogenetic tree was constructed using the CLC Free Workbench 4.5.1 program. The 16S rRNA gene sequences determined in this research have been deposited in the GenBank database of NCBI under the accession numbers: EU877075, EU877078, EU877076 and EU877077 for strains, EC3_2001, EC1_2004, EC3_3502 and EC2_3502, respectively.

Culture conditions

The research was conducted in a batch bioreactor with a functional capacity of $2 \mathrm{dm}^{3}$. Bacteria were grown in mineral medium, the composition of which was described 
previously (Greń et al. 2009), supplemented with $47 \mathrm{~g} \mathrm{~m}^{-3}$ or $124 \mathrm{~g} \mathrm{~m}^{-3}$ vinyl acetate. Every experiment was conducted under the same conditions: volume of the suspended matter $1,500 \mathrm{ml} ; \mathrm{pH} 7$; temperature $30^{\circ} \mathrm{C}$; stirring $130 \mathrm{rpm}$. The $\mathrm{pH}$ of the medium was adjusted to 7 by adding a $10 \%$ solution of $\mathrm{KOH}$. Because of the volatility of the substrate and intermediates oxygen could not be supplied by air sparging. A constant DO (dissolved

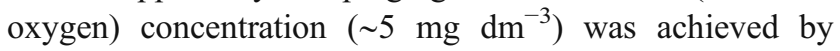
dosage with a $0.75 \%$ solution of hydrogen peroxide.

\section{Analytical methods}

The composition of the fluid cultures was determined by means of gas chromatography. Samples were taken from the cultures under sterile conditions and analysed directly by injection of $0.15 \mu \mathrm{l}$ samples into a Varian 3800 gas chromatograph, equipped with a $30 \mathrm{~m}$ length, $0.53 \mathrm{~mm}$ diameter CP-wax column and a flame ionisation detector (FID). Helium was used as the carrier gas. Separation was achieved with a temperature programme $\left(30^{\circ} \mathrm{C} \mathrm{min}^{-1}\right.$ from $70^{\circ} \mathrm{C}$ to $\left.150^{\circ} \mathrm{C}\right)$. The temperature of injector and the temperature of the FID was $250^{\circ} \mathrm{C}$.

The concentration of biomass was determined by measuring the absorbance of the fluid culture $(\lambda=$ $550 \mathrm{~nm})$.

\section{Preparation of inoculum}

The bacterial strains were grown in $100 \mathrm{ml}$ mineral salts medium supplemented with $400 \mathrm{~g} \mathrm{~m}^{-3}$ vinyl acetate introduced directly to the medium every $24 \mathrm{~h}$. The flasks were incubated with shaking $(130 \mathrm{rpm})$ at $30^{\circ} \mathrm{C}$. After 3 weeks of preincubation the cells were used as inoculum for the bioreactor.

Preparation of crude enzyme extract

Bacteria were pre-grown in $500 \mathrm{ml}$ mineral medium supplemented with vinyl acetate at a concentration of $400 \mathrm{~g} \mathrm{~m}^{-3}$ added to the culture every $24 \mathrm{~h}$ as a source of carbon and energy. The strain was grown aerobically for 5 days in a shaker at $130 \mathrm{rpm}$ in $30^{\circ} \mathrm{C}$ in $1,000 \mathrm{ml}$ flasks before harvesting. Cells were harvested in the late exponential phase of growth by centrifugation at $4,612 \mathrm{~g}$, for 20 min at $4{ }^{\circ} \mathrm{C}$. The supernatant was left and kept at $4^{\circ} \mathrm{C}$ to the analysis. The cells were washed in $100 \mathrm{ml}$ of $100 \mathrm{mM}$ phosphate buffer ( $\mathrm{pH} 7.5)$, and resuspended in the same buffer. Disruption of the cells was performed by sonicating six times for $15 \mathrm{~s}$. Cell debris was removed by centrifugation $\left(9,000 \mathrm{~g}\right.$, for $30 \mathrm{~min}$ at $\left.4^{\circ} \mathrm{C}\right)$. The clear supernatant was used as the crude cell extract for enzyme assays.
Protein assays

The protein concentration was estimated using the Bradford method with lysozyme as a standard (Bradford 1976).

Enzyme assays

Esterase activity was determined spectrophotometrically using $p$-nitrophenyl butyrate ( $p \mathrm{NPB}$ ) dissolved in dimethyl sulfoxide (DMSO) as a substrate. Esterase activity was determined in $100 \mathrm{mM}$ phosphate buffer ( $\mathrm{pH}$ 7.5), and the final concentration of substrate in the reaction mixture was $1 \mathrm{mM}$. The amount of liberated $p$-nitrophenol (pNP) was determined at $410 \mathrm{~nm}$ at $30^{\circ} \mathrm{C}$. The increase in absorbance was monitored for $3 \mathrm{~min}$ after addition of $25 \mu \mathrm{l}$ crude cell extract. The molar absorbance coefficient for $p$ NPB was $18,400 \mathrm{M}^{-1} \mathrm{~cm}^{-1}$. One unit (U) of esterase activity was defined as the amount of enzyme releasing $1 \mu \mathrm{mol}$ pNP per minute under assay conditions.

Dehydrogenase activities were determined spectrophotometrically in $100 \mathrm{mM}$ phosphate buffer with $750 \mu \mathrm{l} 20 \mathrm{mM}$ $\mathrm{NAD}^{+}$or NADH and $100 \mu \mathrm{l}$ crude cell extract at $340 \mathrm{~nm}$ at room temperature. Reaction substrates were: $95 \%$ ethanol for alcohol dehydrogenase and $100 \mathrm{mM}$ acetaldehyde for aldehyde and alcohol dehydrogenase. One unit of enzyme was defined as the amount of enzyme catalysing formation of $1 \mu \mathrm{mol} \mathrm{NADH} / \mathrm{NAD}^{+}$per minute. The molar absorbance coefficient for NADH/NAD ${ }^{+}$at $340 \mathrm{~nm}$ was $6,220 \mathrm{M}^{-1} \mathrm{~cm}^{-1}$.

\section{Results and discussion}

Identification of isolated strains degrading high concentrations of vinyl acetate

Identification of the four Gram-negative strains was based on morphological, biochemical and genetic methods. All strains grew on nutrient agar plates as circular, opaque, creamy-coloured colonies. The biochemical and physiological characteristics of the isolated strains are summarised in Table 1. Three of the isolated strains exhibited catalase and oxidase activities, while nitrate reduction was found only in cells of strains denoted as EC2_3502 and EC3_3502. Glucose was the only substrate assimilated by all isolated strains.

Analysis of the fatty acids pattern (Table 2) showed the largest contribution of fatty acids with a hydroxyl in the third position from the acid end and palmitic acid, which were listed by Kozdrój and van Elsas (2001) as most typical of Gram-negative bacteria and the genus Pseudomonas, respectively. The patterns generated with API 20NE tests were in good agreement with the results obtained from fatty acid patterns and allowed strains 
Table 1 Differential phenotypic characteristics of isolated strains

\begin{tabular}{|c|c|c|c|c|}
\hline Characteristic & EC3_2001 & EC1_2004 & EC2_3502 & EC3_3502 \\
\hline Nitrate reduction & - & - & + & + \\
\hline Indol production & - & - & - & - \\
\hline Fermentation of glucose & - & - & - & - \\
\hline Arginine dihydrolase & + & + & - & - \\
\hline Urease & - & - & - & - \\
\hline Hydrolysis of esculin & - & - & + & - \\
\hline Hydrolysis of gelatin & - & - & - & - \\
\hline Oxidase & + & + & - & + \\
\hline Catalase & + & + & - & + \\
\hline Beta-galactosidase & - & - & + & - \\
\hline \multicolumn{5}{|l|}{ Assimilation of: } \\
\hline Glucose & + & + & + & + \\
\hline Arabinose & - & + & + & - \\
\hline Mannose & + & - & + & - \\
\hline Mannitol & - & + & + & - \\
\hline $\mathrm{N}$-acetyl-glucosamine & - & - & + & - \\
\hline Maltose & - & - & + & - \\
\hline Gluconate & + & - & - & + \\
\hline Caprate & + & + & - & - \\
\hline Adipate & - & + & - & - \\
\hline Malate & + & - & + & + \\
\hline Citrate & + & + & - & + \\
\hline Phenylacetate & + & + & - & + \\
\hline
\end{tabular}

EC3_2001 and EC1_2004 to be classified as Pseudomonas putida, strain EC3_3502 as Achromobacter xylosooxidans and EC2_3502 as Agrobacterium sp.

In order to confirm the phylogenetic relationships of the isolated strains, genomic DNAs were isolated and the genes

Table 2 Percentage of total fatty acids from the isolated strains

\begin{tabular}{lllll}
\hline Fatty acid $^{\mathrm{a}}$ & EC3_2001 & EC1_2004 & EC2_3502 & EC3_3502 \\
\hline $10: 03 \mathrm{OH}$ & 7.82 & 7.47 & - & - \\
$12: 0$ & 2.03 & 1.82 & - & - \\
$12: 02 \mathrm{OH}$ & 7.69 & 6.26 & - & - \\
$12: 03 \mathrm{OH}$ & 6.32 & 5.46 & - & - \\
$14: 0$ & - & - & - & 1.49 \\
$15: 0$ anteiso & - & 1.18 & - & - \\
$16: 0$ & 27.79 & 26.61 & 8.61 & 38.19 \\
$16: 0$ 3OH & - & - & 4.98 & - \\
17:0 anteiso & 0.93 & 1.04 & 1.47 & - \\
$17: 0$ cyclo & 22.03 & 11.06 & - & 11.24 \\
18:0 & - & - & - & 3.17 \\
19:0 cyclo $\omega 8 \mathrm{c}$ & 1.33 & - & 4.39 & - \\
19:0 10 methyl & - & - & 1.15 & - \\
\hline
\end{tabular}

${ }^{a} \omega$ Methyl end of fatty acid, c cis configuration of the double bond, cyclo cyclopropane fatty acid, iso branched fatty acids, $\mathrm{OH}$ indicates the position of hydroxyl group from the acid end coding for $16 \mathrm{~S}$ rRNA were amplified. The nearly complete 1,434-bp-long 16S rRNA gene sequence of strain EC3_2001 was found to be $96 \%$ identical to that of Pseudomonas sp. D25 (DQ887517.1). A high percentage (95\%) identity was also found with $P$. putida strain 757 (EU4300087.1). The almost complete 1,441-bp-long $16 \mathrm{~S}$ rRNA gene sequence of strain EC1_2004 was found to be 99\% identical to that of strain 757 (Fig. 1). The 1,446-bp-long 16S rRNA gene sequence of strain EC3_3502 was found to be 98\% identical to that of Achromobacter sp. IL-02 (DQ989212.2) and Achromobacter xylosoxidans strain B8L (DQ466568.1) (Fig. 1). The nearly complete 1,415-bp-long 16S rRNA gene sequence of strain EC2_3502 was found to be $94 \%$ identical to that of Agrobacterium sp. 24DA-1 (DQ278905.1). A high percentage $(96 \%)$ of identity was also found with Agrobacterium tumefaciens strain LZD29 (GQ861463.1) (Fig. 1). In accordance with these data, the isolates EC3_2001 and EC1_2004 were included in the genus

Fig. 1 Neighbour-joining tree showing the phylogenetic position of EC3_2001 and EC1_2004, EC3_3502, EC2_3502 strains and related species based on partial $\overline{16} \mathrm{~S}$ rRNA gene sequences. The GenBank accession number for each microorganism used in the analysis is shown in parentheses after the species name. Bootstrap values (expressed as percentage of 100 replicons) are shown at the branches 
- Pseudomonas sp. SeaH-As7w (FJ607358.1)
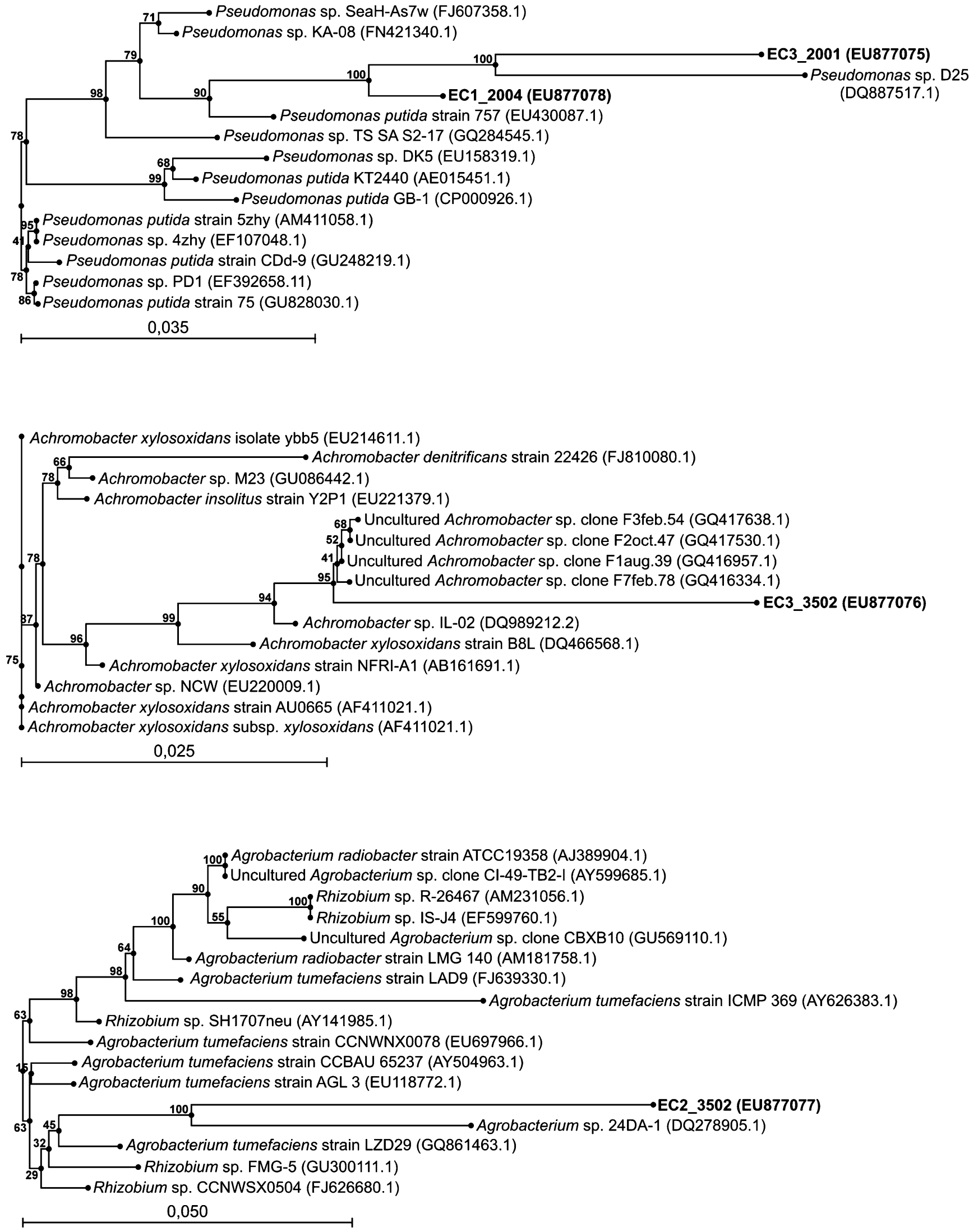
Pseudomonas and named as P. putida EC3_2001 and EC1_2004, respectively. The isolate EC3 3502 was included in the genus Achromobacter and EC2_3502 in the genus Agrobacterium and named as Achromobacter xylosoxidans EC3_3502 and Agrobacterium sp. EC2_3502, respectively.
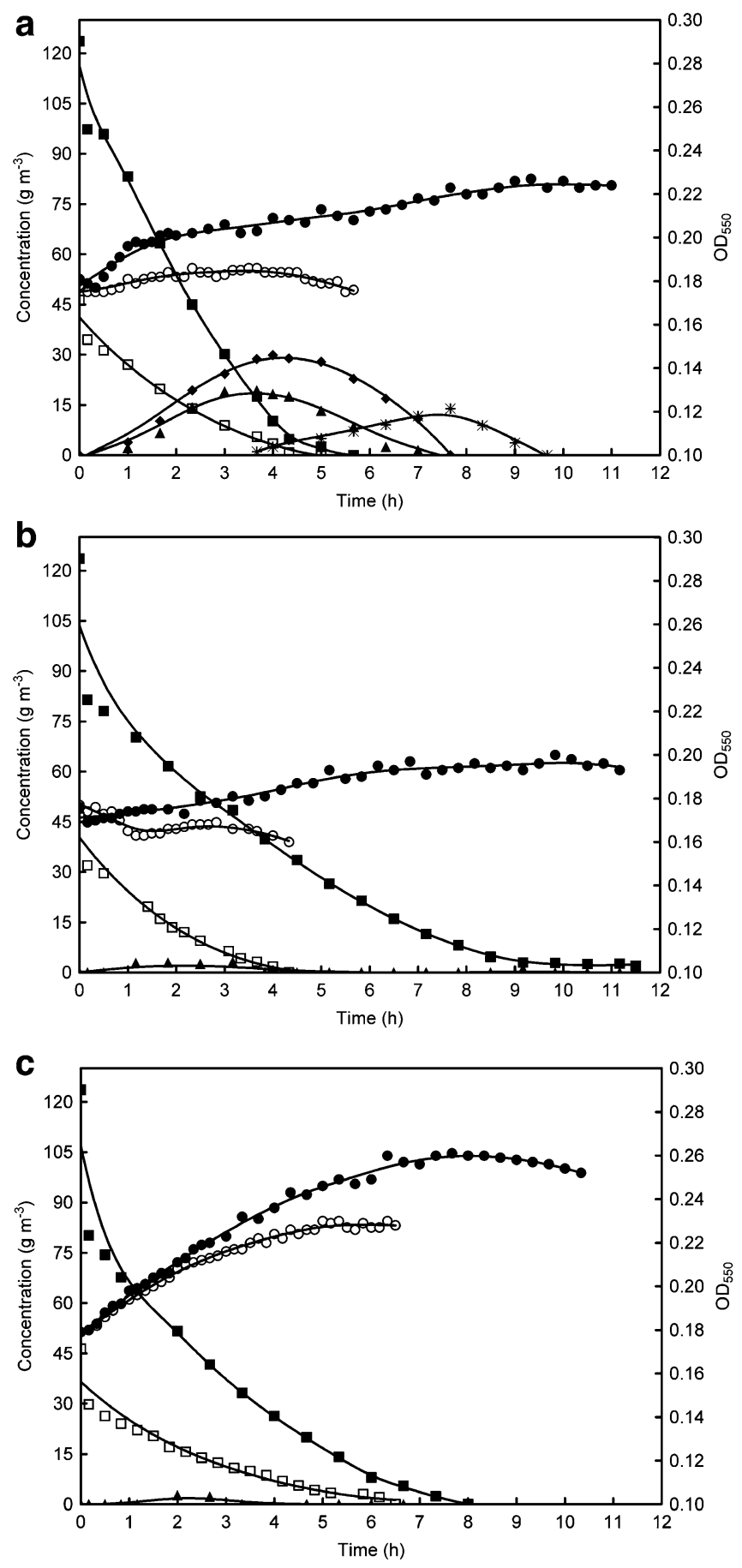

Fig. 2 Degradation of $47 \mathrm{~g} \mathrm{~m}^{-3}$ (white symbols) and $124 \mathrm{~g} \mathrm{~m}^{-3}$ (black symbols) of vinyl acetate under aerobic conditions. a EC3 2001, b EC1_2004, c EC3_3502, d PCM 2123, e KB2; circles optical
Bacteria belonging to the genus Pseudomonas are known to be good degraders of numerous harmful substances such as aliphatic and aromatic hydrocarbons or fatty acids (Lalucat et al. 2006). Representatives of the genus Achromobacter are described as microorganisms able
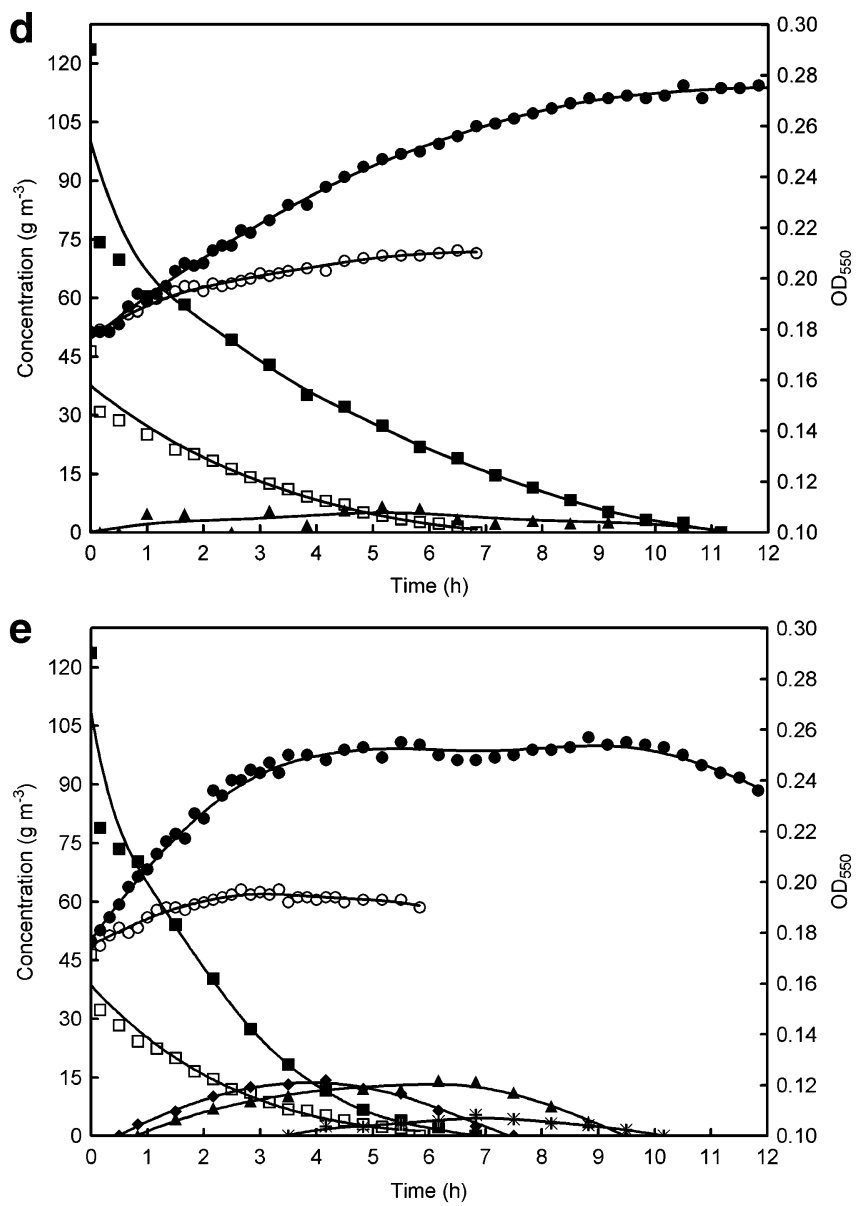

density at $550 \mathrm{~nm}$, squares vinyl acetate, triangles acetic acid, diamonds acetaldehyde, asterisks ethanol 
to degrade different chemical compounds including VOCs (Nielsen et al. 2006; Wan et al. 2007; Eixarch and Constanti 2010). There are some reports concerning decomposition of organic compounds by Agrobacterium strains, mainly Agrobacterium radiobacter (Higgins et al. 1993; Struthers et al. 1996). So far only Nieder et al. (1990) have described a Gram-negative strain (V2) using vinyl acetate as the sole source of carbon and energy, and Hatanaka et al. (1989) described esterases of Pseudomonas sp. Z2 strain, only one of which was involved in cleavage of the ester bond of vinyl acetate.

Degradation of vinyl acetate under aerobic conditions

Degradation of $47 \mathrm{~g} \mathrm{~m}^{-3}$ and $124 \mathrm{~g} \mathrm{~m}^{-3}$ vinyl acetate was studied for only three of the isolated species. Because Agrobacterium sp. strain EC2_3502 was catalase negative (Table 1), it was unable to decompose vinyl acetate in the presence of oxygen provided in hydrogen peroxide. As controls, P. fluorescens PCM 2123 and Stenotrophomonas malthophilia KB2 were used (Fig. 2).

The time required to degrade vinyl acetate at a concentration of $47 \mathrm{~g} \mathrm{~m}^{-3}$ varied between the described strains, with the shortest time being observed in cultures of $P$. putida strains. The fastest degradation rate of $124 \mathrm{~g} \mathrm{~m}^{-3}$ vinyl acetate was observed for strain P. putida EC3_2001, Achromobacter xylosoxidans EC3_3502 and Stenotrophomonas malthophilia KB2. But the result of quick hydrolysis of the ester bond was the accumulation of acetic acid and acetaldehyde in the culture fluid of EC3_2001 and KB2 strains. Acetaldehyde at a concentration of $10 \mathrm{~g} \mathrm{~m}^{-3}$ was found to retard microbial growth, and a dose of $13 \mathrm{~g} \mathrm{~m}^{-3}$ completely inhibited any increase in biomass but not vinyl acetate metabolism. A decrease in the acetaldehyde concentration was correlated with a temporary increase in ethanol concentration (Fig. 2a,e). A constant ethanol concentration of about $2-5 \mathrm{~g} \mathrm{~m}^{-3}$ was maintained during the entire incubation period in most cultures, but ethanol was finally metabolised directly to acetic acid because no successive accumulation of acetaldehyde was observed. In the cultures of three strains, EC3_3502, PCM
2123 and KB2, complete transformation of vinyl acetate was seen together with proliferation of the bacterial strain (Fig. 2c-e). The same results were described by Nieder et al. (1990) for Gram-negative isolate V2. Intermediates of vinyl acetate hydrolysis did not appear in the culture fluid, and a visual increase in optical density of the culture accompanied the complete decomposition of vinyl acetate. In contrast, intensive growth of Stenotrophomonas malthophilia KB2 was observed until acetaldehyde appeared in the culture fluid, suggesting its toxic influence on cells of strain KB2.

Enzyme activities involved in vinyl acetate decomposition under aerobic conditions

The first step of vinyl acetate biodegradation by the described strains under aerobic conditions is hydrolysis of the ester bond due to esterase activities (Table 3). No esterase activities were found in the extracellular fraction obtained after centrifugation of the culture fluids of the described strains (data not shown). Higher esterase activity was combined with a higher vinyl acetate degradation rate and shorter decomposition time by EC3_2001, PCM 2123 and KB2 strains. The levels of oxidoreductases activities involved in the vinyl acetate degradation rate were lower in comparison to the esterase specific activities determined in crude cell extracts. The presence of both alcohol dehydrogenase and aldehyde dehydrogenase confirmed our previous suggestions that periodic transformation of acetaldehyde to ethanol could be a defence mechanism against acetaldehyde toxicity. Further studies on the kinetics of enzymes engaged in vinyl acetate degradation are ongoing.

Effect of oxygen deficiency on vinyl acetate decomposition

Due to the conditions of temporary oxygen shortage that occur during operation of a trickle-bed reactor, biodegradation of $124 \mathrm{~g} \mathrm{~m}^{-3}$ vinyl acetate under oxygen deficiency was studied for all isolated and control strains. Oxygen deficiency inhibited neither growth of bacterial strains nor degradation of vinyl acetate, in comparison to studies carried out under
Table 3 Specific esterase and dehydrogenases activities (mU mg ${ }^{-1}$ protein) in crude cell extracts of the described strains after 5-days induction with vinyl acetate at a concentration of $400 \mathrm{~g} \mathrm{~m}^{-3}$ under aerobic conditions. The results are an average of at least three independent measurements

\begin{tabular}{|c|c|c|c|c|}
\hline \multirow[b]{2}{*}{ Substrate } & \multirow{2}{*}{$\frac{\text { Esterase }}{p \mathrm{NPB}}$} & \multirow{2}{*}{$\frac{\text { Alcohol dehydrogenase }}{\text { Ethanol }}$} & \multirow{2}{*}{$\frac{\text { Alcohol dehydrogenase }}{\text { Acetaldehyde }}$} & \multirow{2}{*}{$\begin{array}{l}\text { Aldehyde dehydrogenas } \\
\text { Acetaldehyde }\end{array}$} \\
\hline & & & & \\
\hline \multicolumn{5}{|l|}{ Strain } \\
\hline EC3_2001 & $694 \pm 46$ & $10.22 \pm 2.46$ & $66.21 \pm 12.22$ & $7.21 \pm 2.10$ \\
\hline EC1_2004 & $323 \pm 119$ & $3.11 \pm 0.89$ & $5.21 \pm 2.12$ & $5.22 \pm 1.45$ \\
\hline EC2_3502 & $436 \pm 120$ & $11.34 \pm 2.78$ & $12.23 \pm 3.29$ & $23.66 \pm 10.09$ \\
\hline EC3_3502 & $720 \pm 22$ & $2.03 \pm 0.15$ & $10.02 \pm 2.55$ & $4.74 \pm 1.34$ \\
\hline PCM 2123 & $638 \pm 166$ & $9.67 \pm 3.13$ & $58.34 \pm 16.17$ & $3.67 \pm 1.23$ \\
\hline KB2 & $724 \pm 40$ & $12.09 \pm 4.55$ & $36.89 \pm 10.02$ & $9.67 \pm 1.11$ \\
\hline
\end{tabular}



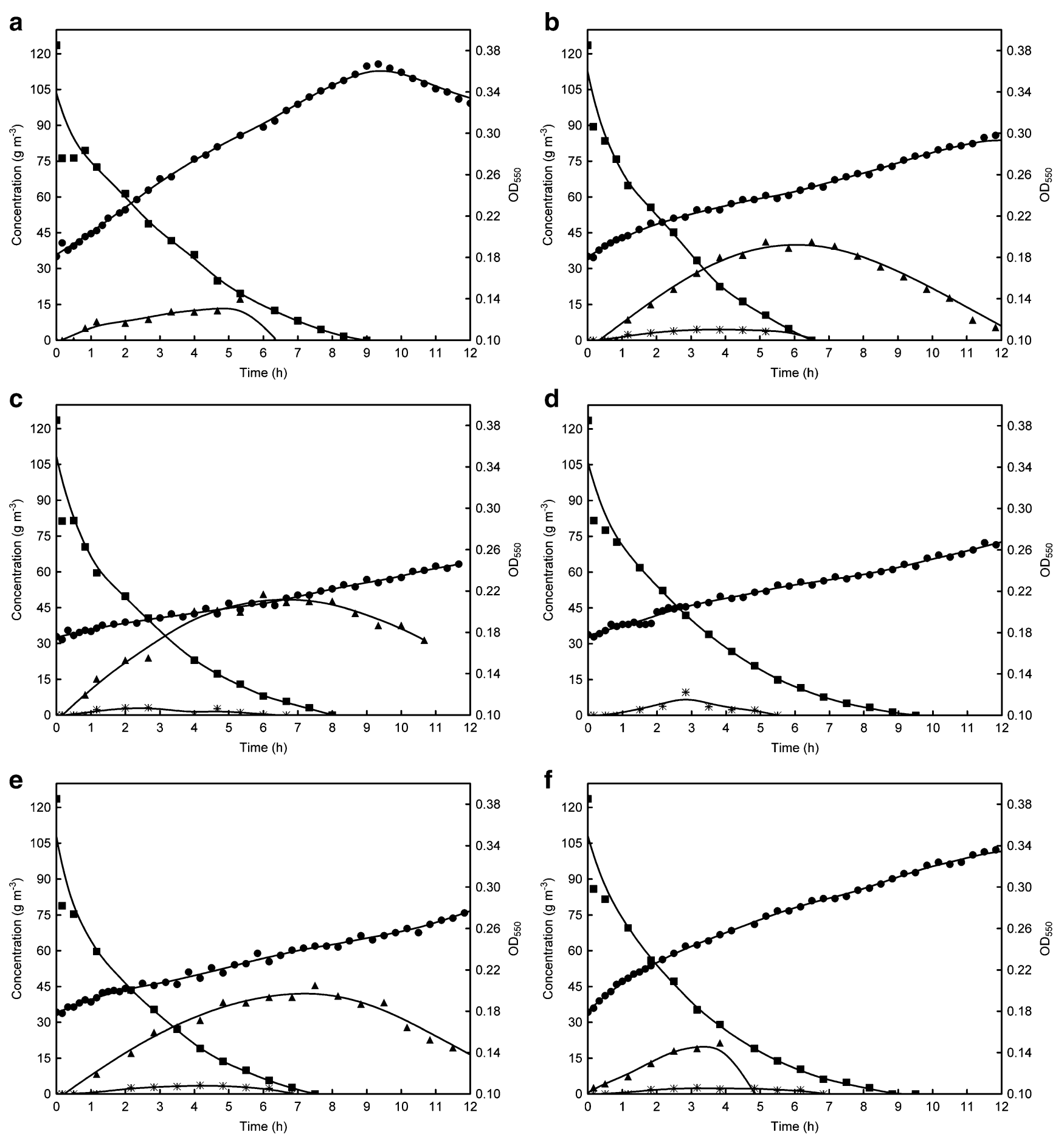

Fig. 3 Degradation of $124 \mathrm{~g} \mathrm{~m}^{-3}$ vinyl acetate under oxygen deficiency. a EC3_2001, b EC1_2004, c EC3_3502, d EC2_3502, e PCM 2123, f KB2; circles optical density at $550 \mathrm{~nm}$, squares vinyl acetate, triangles acetic acid, diamonds acetaldehyde, asterisks ethanol

aerobic conditions (Fig. 3). The most abundant intermediate of vinyl acetate decomposition in all the described strains except for Agrobacterium sp. EC2_3502 (Fig. 3d) was acetic acid. The lowest concentrations of acetic acid were observed in the cultures of intensively proliferating cells of EC3_2001 and KB2 strains. In addition, small amounts of ethanol were detected in the culture fluids of all strains apart from P. putida EC3_2001 (Fig. 3a). Ethanol was also found as an intermediate of incomplete decomposition of vinyl acetate under $\mathrm{N}_{2}$ by strain V2 (Nieder et al. 1990), while the initial concentration of vinyl acetate did not exceed $15 \mathrm{mM}$. In the presence of higher concentrations of vinyl acetate, the presence of an additional intermediateacetaldehyde — was confirmed. 


\section{Conclusions}

Biochemical, physiological and genetic tests allowed the isolated strains to be identified as $P$. putida EC3 2001, $P$. putida EC1_2004, Achromobacter xylosoxidans EC3_3502 and Agrobacterium sp. EC2_3502. The described strains were able to effect the complete mineralisation of vinyl acetate without any accumulation of harmful end-products. Lack of catalase activity precluded usage of EC2_3502 strain in vinyl acetate decomposition under the required experimental conditions. The main criterion of strain selection was biomass production in order to prevent future biological clogging and physical plugging during operation of the trickle-bed bioreactor. Because the bioreactor operates for long periods under aerobic conditions, the two P. putida strains would seem to be the best microorganisms for vinyl acetate removal. Although the decomposition time of vinyl acetate by strain EC1_2004 was longer than that of EC3_2001, the absence of toxic intermediates during degradation makes $P$. putida EC1_2004 strain the best vinyl acetate degrader of the strains tested here.

Acknowledgements The authors would like to thank Agnieszka Materna for excellent technical assistance. This research was financially supported by grant PBZ-MEiN-3/2/2006 titled: "Process engineering for the abatement of harmful and greenhouse gas emissions and their utilization".

Open Access This article is distributed under the terms of the Creative Commons Attribution Noncommercial License which permits any noncommercial use, distribution, and reproduction in any medium, provided the original author(s) and source are credited.

\section{References}

Bradford MM (1976) A rapid and sensitive method for the quantitation of microgram quantities of protein utilizing the principle of protein-dye binding. Anal Biochem 72:248-258

Eixarch H, Constanti M (2010) Biodegradation of MTBE by Achromobacter xylosoxidans MCM1/1 induces synthesis of proteins that may be related to cell survival. Process Biochem 45:794-798. doi:10.1016/j.procbio.2009.12.015

Glucksman AM, Skipper HD, Brigmon RL, Santo Domingo JW (2000) Use of the MIDI-FAME technique to characterize groundwater communities. J Appl Microbiol 88:711-719

Greń I, Gąszczak A, Szczyrba E, Łabużek S (2009) Enrichment, isolation and susceptibility profile to the growth substrate of bacterial strains able to degrade vinyl acetate. Pol J Environ Stud 18:383-390

Guzik U, Greń I, Wojcieszyńska D, Łabużek S (2009) Isolation and characterization of a novel strain of Stenotrophomonas maltophilia possessing various dioxygenases for monocyclic hydrocarbon degradation. Braz J Microbiol 40:285-291
Hatanaka Y, Inoue Y, Murata K, Kimura A (1989) A isolation and characterization of carboxylesterase from vinyl acetate-assimilating bacterium isolated from soil. J Ferment Bioeng 67:14-19

Higgins TP, Snake JR, White GF (1993) Comparison of pathways for biodegradation of monomethyl sulphate in Agrobacterium and Hyphomicrobium species. J Gen Microbiol 139:2915-2920. doi:10.1099/00221287-139-12-2915

Holt JG, Krieg NR, Sneath PHA, Staley JT, Williams ST (1994) Bergey's manual of determinative bacteriology. Williams and Wilkins, Baltimore

Iliuta I, Larachi F (2004) Transient biofilter aerodynamics and clogging for VOC degradation. Chem Eng Sci 59:3293-3302. doi:10.1016/j.ces.2004.05.004

Iliuta I, Larachi F (2005) Modeling simultaneous biological clogging and physical plugging in tricke-bed bioreactors for wastewater treatment. Chem Eng Sci 60:1477-1489. doi:10.1016/j.ces.2004.10.016

Jakoby WB, Narrod SA (1958) Aldehyde oxidation IV. An aldehyde buffer for growth studies. J Bacteriol 77:410-413

Kennes C, Veiga MC (2001) Bioreactors for waste gas treatment. Kluwer, Dordrecht

Kozdrój J, van Elsas JD (2001) Structural diversity of microorganisms in chemically perturbed soil assessed by molecular and cytochemical approaches. J Microbiol Methods 43:197-212

Lalucat J, Bennasar A, Bosch R, Garcia-Valde E, Palleroni NJ (2006) Biology of Pseudomonas stutzerii. Microbiol Mol Biol Rev 70:510-547. doi:10.1128/MMBR.00047-05

Lonergan DJ, Jenter HL, Coates JD, Phillips EJ, Schmidt TM, Lovley DR (1996) Phylogenetic analysis of dissimilatory Fe (III) - reducing bacteria. J Bacteriol 178:2402-2408

Malhautier L, Khammar N, Sandrine B, Fanlo J-L (2005) Biofiltration of volatile organic compounds. Appl Microbiol Biotechnol 68:16-22. doi:10.1007/s00253-005-1960-Z

Mendoza JA, Prado ÓJ, Veiga MC, Kennes C (2004) Hydrodynamic behaviour and comparison of technologies for the removal of excess biomass in gas-phase biofilters. Water Res 38:404-413. doi:10.1016/j.watres.2003.09.014

Nieder M, Sunarko B, Meyer O (1990) Degradation of vinyl acetate by soil, sewage, sludge, and the newly isolated aerobic bacterium V2. Appl Environ Microbiol 56:3023-3028

Nielsen DR, MbLellan PJ, Daugulis AJ (2006) Direct estimation of the oxygen requirements of Achromobacter xylosoxidans for aerobic degradation of monoaromatic hydrocarbons (BTEX) in a bioscrubber. Biotechnol Lett 28:1293-1298. doi:10.1007/s10529. 006-9093-8

Sasser M (1990) Technical note 101-110. Tracking a strain using the Microbial Identification System. MIS, Newark, DE

Struthers JK, Jayachandran K, Moorman TB (1996) Biodegradation of atrazine by Agrobacterium radiobacter J14a and use of this strain in bioremediation of contaminated soil. Appl Environ Microbiol 64:3368-3375

Takeuchi M, Weiss N, Schumann P, Yokota A (1996) Leucobacter komagatae gen. nov., sp. nov., a new aerobic Gram-positive, nonsporulating rod with 2, 4-diaminobutyric acid in the cell wall. Int J Syst Bacteriol 4:967-971

US Environmental Protection Agency. Vinyl acetate (1992/2007) Technology Transfer Network Air Toxic Web Site. http://www. epa.gov/ttn/atw/hlthef/vinylace.html

Wan N, Gu J-D, Yan Y (2007) Degradation of $p$-nitrophenol by Achromobacter xylosoxidans Ns isolated from wetland sediment. Int Biodeterior Biodegrad 59:9096. doi:10.1016/j.ibiod.2006.07.012 